\title{
ĐÁNH GIÁ KẾT QUẢ SỚM PHẪU THUẠTT SANDWICH ĐIỀU TRI DỊ DẠNG LỒI NGỰC BẨM SINH
}

\section{TÓM TÁT:}

27 truờng hơp lồi ngực được phẫu thuạt (17 nam và 10 nũ)), tuổi trung bình là 7 tuổi. Thời gian phẫu thuật trung bình là 45 phút, thời gian nằm viện sau phẫu thuật trung bình là 4 ngày, không có tử vong, tai biến hậu phẫu. Phẫu thuật Sandwich là phwoong pháp phẫu thuật it xâm lấn trong điều trị dị dạng lồi ngục bẩm sinh. Kết quả buớc đầu cho thấy đây là phuoong pháp an toàn, thời gian hồi phuc nhanh, hiệu quả và có tính thẩm mỹ cao.

Tù̀ khóa: Lồi ngực, phẫu thuật Sandwich.

\section{SUMMARY}

\section{EARLY RESULTS AFTER TREATMENT OF CONGENITAL PECTUS CARINATUM BY SANDWICH PROCEDURE}

27 patients, 17 men and 10 women,
Trần Thanh Vỹ , Lê Quang Đình", Hồ Tất Bằng ${ }^{* *}$ mean age is 7. Mean length of surgery was 45 minutes, hospital stay after intervention was 4 days. No patients died and had postoperative complications. Sandwich procedure is a minimally invasive surgical treatment of congenital pectus carinatum. Initial results show that this method is safe, effective and highly aesthetic.

Keyword: Pectus carinatum, Sandwich procedure.

\section{GIỚI THIỆU}

Dị dạng lồi ngực (hay còn gọi là ngực ức gà) là một bất thường bẩm sinh của thành ngực trước, phổ biến thứ hai sau lõm ngực. Đặc trưng của dị tật này là xương ức và khung sườn phía trước nhô ra bất thường gây ảnh đến thẩm mỹ, tạo tâm lý mặc cảm, chức năng hô hấp ít nhiều bị ảnh hưởng []] []].
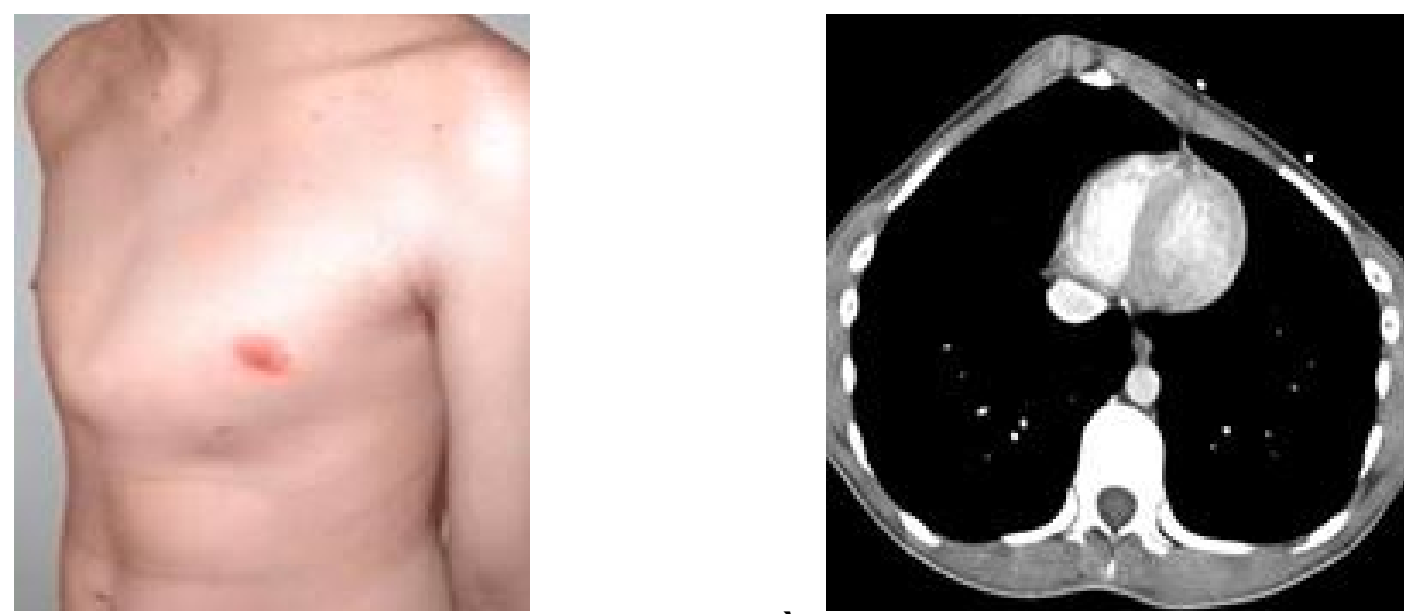

\section{Hình 1: Dị dạng lồi ngục}

\footnotetext{
* Khoa Lồng ngục Mạch máu - Bệnh viện Đại Học Y Dược TP.HCM **Bộ môn phấu thuật lồng ngưc tim mạch-Đại Học Y Dược TPHCM Người chịu trách nhiệm khoa học: Ths Trần Thanh Vỹ

Ngày nhận bài: 15/07/2018 - Ngày Cho Phép Đăng: 20/07/2018 Phản Biện Khoa học: PGS.TS. Đặng Ngọc Hùng

GS.TS. Lê Ngọc Thành
} 
Lồi ngực bẩm sinh có tỉ lệ vào khoảng 1:1000 trẻ, ít hơn so với lõm ngực (1:400). Lồi ngực ở nam nhiều gấp 4 lần so với nữ. Khoảng $25 \%$ bệnh nhân có người thân mắc dị dạng lồi ngực. $20 \%$ bệnh nhân có kèm theo bệnh lý tim bẩm sinh, $22 \%$ có kèm vẹo xương sống [4]

\section{MộT SỐ PHƯƠNG PHÁP ĐIỀU} TR!̣ LỒI NGỤ̂C

\section{1. Đeo khung chỉnh sửa}

- Hiệu quả hạn chế, không triệt để, thường
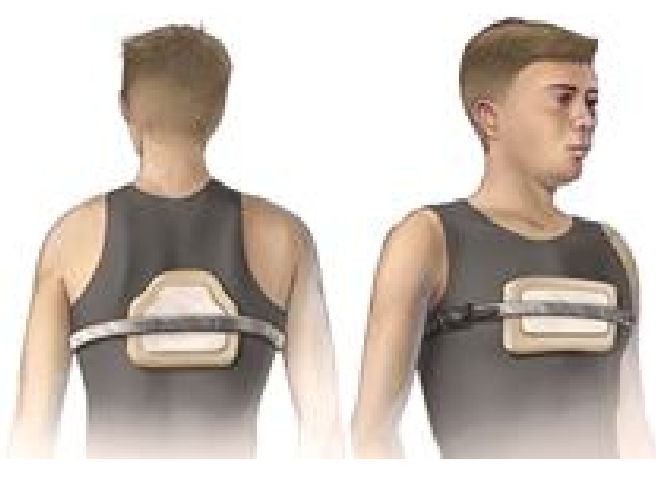

Hình 2: Đeo khung chỉnh sưa không có tác dụng trong những trường hợp lồi ngực nặng hoặc lồi ngực kết hợp lõm ngực.

- Đeo khung thường xuyên và kéo dài gây bất tiện trong sinh hoạt

- Đòi hỏi người bệnh phải tuân thủ điều trị, tái khám định kỳ, thời gian điều trị kéo dài

- Một số trường hợp dị ứng da, thay đổi sắc tố da do tiếp xúc với khung ép thường xuyên trong thời gian dài.

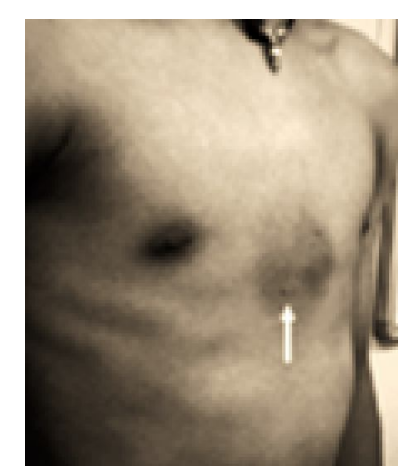

Hình 3: Chàm da sau thời gian dài đeo khung chinh süa

2.2. Phẫu thuật Ravitch : cắt bỏ phần xương ức và sụn sườn nhô ra, kèm theo hay không đặt thanh thép cố định xương ức.

- Xâm lấn nhiều, dễ tổn thương trung thất

- Đau nhiều sau phẫu thuật

- Vấn đề thẩm mỹ do sẹo xấu vùng ngực trước

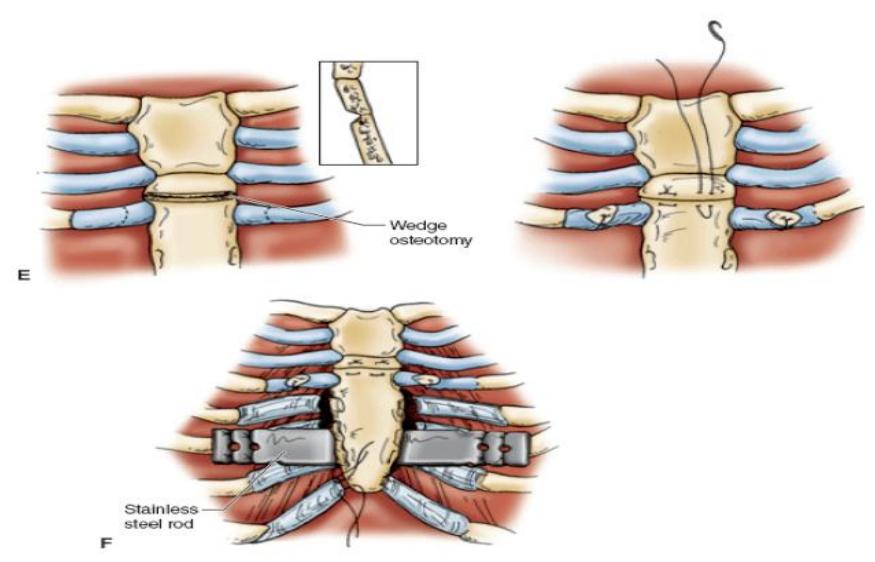

Hình 4: Phẫu thuật Ravitch 

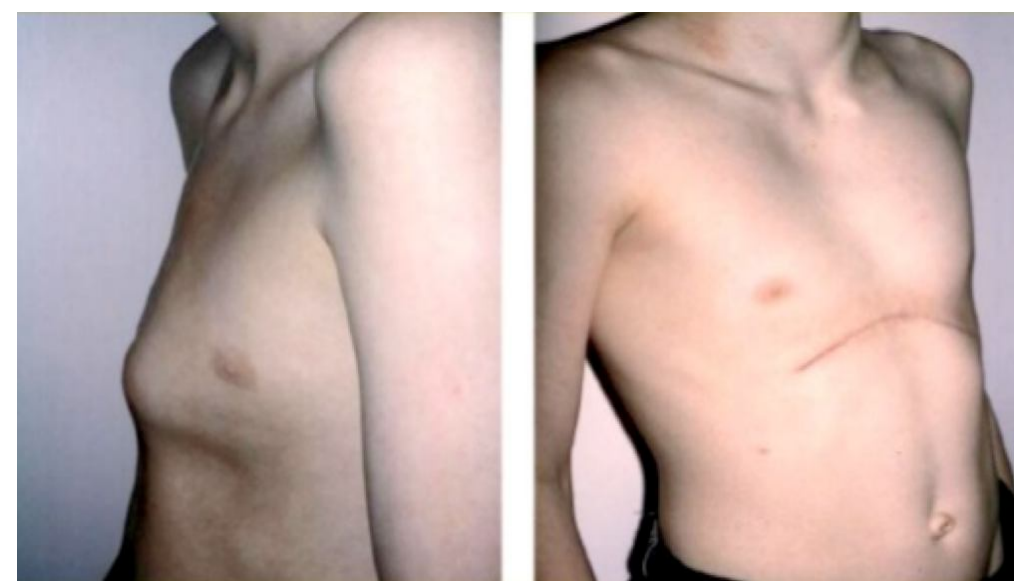

Hình 5: Sẹo sau phẫu thuật Ravitch

2.3. Phẫu thuật Nuss cải biên: phẫu thuật đặt 2 thanh nâng ngực phía trong lồng ngực kết hợp cắt bỏ phần sụn sườn lồi ra, tác giả Vũ Hữu Vĩnh cùng các cộng sự (2015) báo cáo sửa chữa thành công 11 bệnh nhân có dị tật lồi ngực [2]].

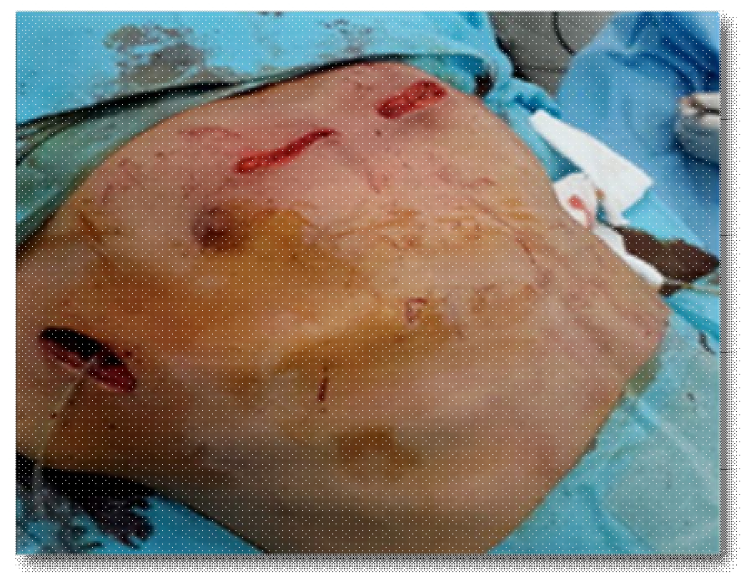

Hình 6: Phẫu thuật Nuss cải biên

2.4. Phẫu thuật Abramson []ㅣ: là phẫu thuật dùng 1 thanh ép bên ngoài lồng ngực. Hiệu quả kém ở những bệnh nhân lồi ngực không đối xứng, lồi ngực kèm lõm ngực.

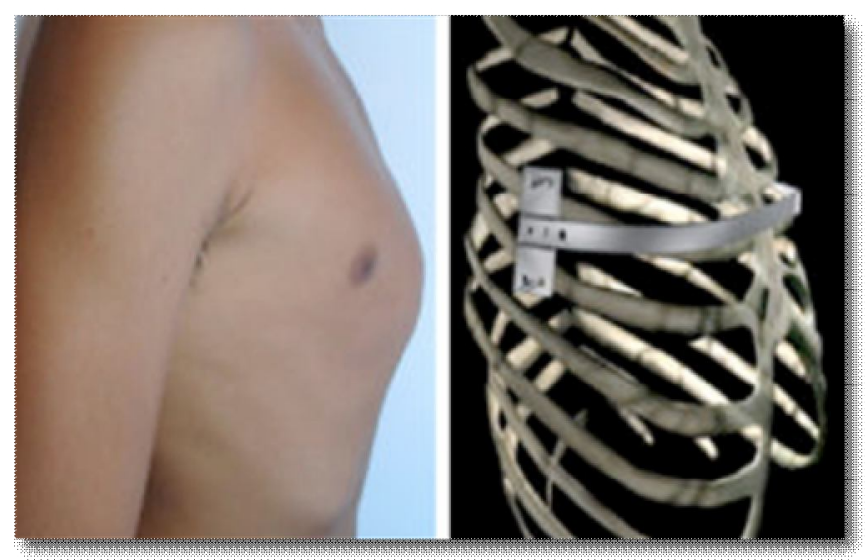

Hình 7: Phẫu thuật Abramson 
2.5. Phẫu thuật Sandwich: tác giả Hyung Joo Park (2016) báo cáo thực hiện thành công 58 bệnh nhân bị lồi ngực và lồi ngực kết hợp lõm ngực bằng cách sử dụng hai thanh kim loại trong và ngoài lồng ngực ép lại, chỉnh sửa dị dạng bằng lực ép giữa hai thanh, đặt tên phẫu thuật Sandwich [7]].

\section{CHỈ ĐỊNH ĐIỀU TRI [7]}

- Lồi ngục bẩm sinh đối xúng

A

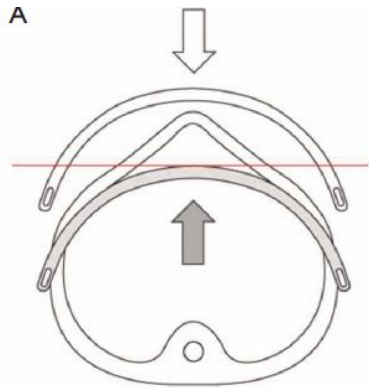

- Lồi ngục bẩm sinh không đối xứng

A

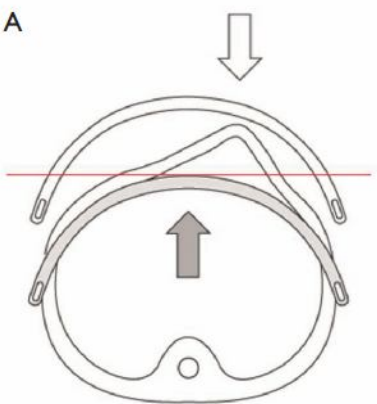

- Lồi ngực kết hợp lõm ngực

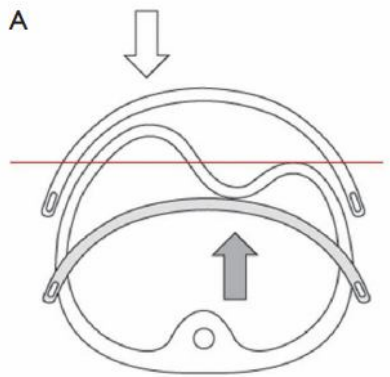

\section{QUY TRİNH PHẪU THUẬT}

- Bệnh nhân được nhập viện, thực hiện các xét nghiệm tiền phẫu, siêu âm tim, đo chức năng hô hấp, khám tiền mê chu phẫu.
Tại bệnh viện Đại học Y Dược TP. Hồ Chí Minh, chúng tôi đã bắt đầu thực hiện phẫu thuật ít xâm lấn điều trị lồi ngực bẩm sinh bằng bộ dụng cụ thanh kép từ tháng $5 / 2016$.

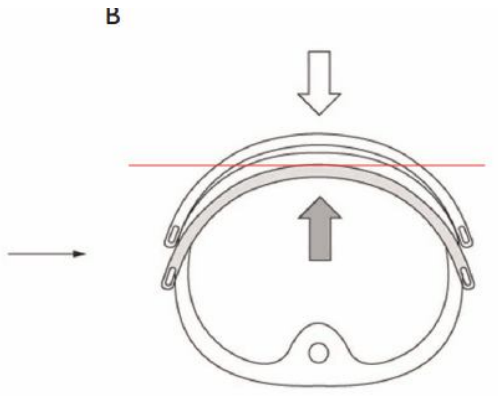

B
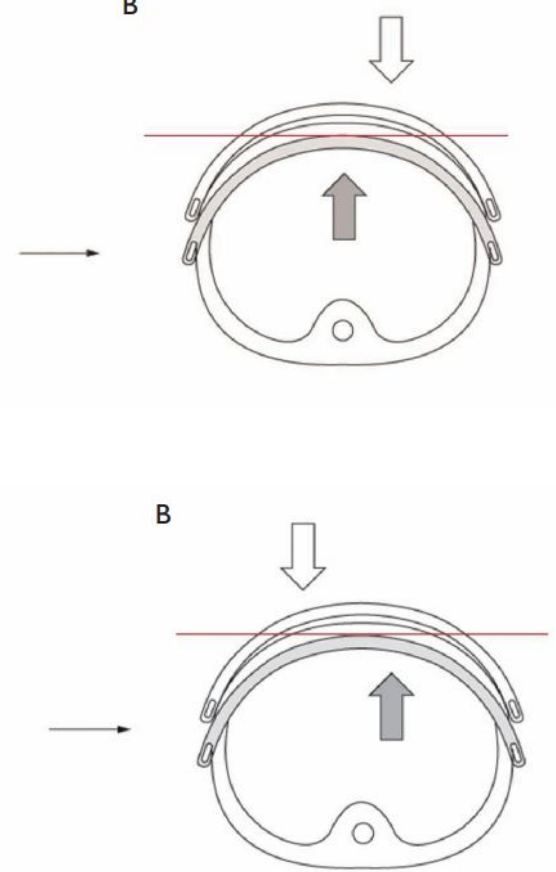

- Chụp cắt lớp vi tính lồng ngực không tiêm thuốc cản quang để đánh giá chính xác hình thái học lồng ngực 
4.1. Bộ dụng cụ phẫu thuật : bao gồm bộ dụng cụ uốn thanh, bộ vít + tua vít kết hợp 2 dụng cụ phẫu thuật cơ bản, hai thanh kim loại: 1 thanh kim loại. thanh trong lồng ngực, 1 thanh ngoài lồng ngực,

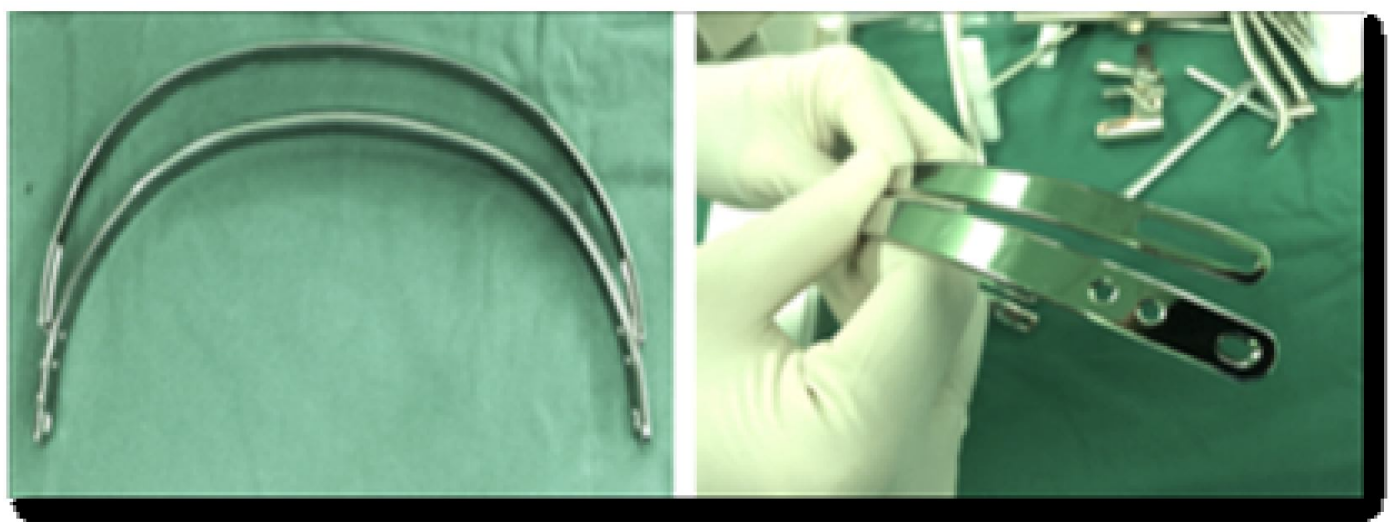

Hình 8: Bộ thanh kép tạo hình lồng ngực

\subsection{Kỹ thuật thực hiện:}

- Bệnh nhân được đặt tư thế nằm ngửa, gây mê nội khí quản, rạch da 2 bên thành ngực $2 \mathrm{~cm}$ ngang với vị trí lồi ngực, bóc tách tạo đường hầm giữa khung sườn và lớp cơ ngực, luồn ống dẫn lưu làm dây dẫn thứ 1

- Tạo đường hầm xuyên trung thất phía sau xương ức bằng clampp cong, luồn ống dẫn lưu làm dây dẫn thứ 2 , qua dây dẫn này, đặt thanh kim loại đã được uốn cong vào trong lồng ngực.
- Qua dây dẫn thứ 1, đặt thanh kim loại đã được uốn cong vào bên ngoài lồng ngực, dưới các lớp cơ. dùng vít cố định hai thanh phía bên phải.

- Dùng kềm chuyên dụng tạo lực ép giữa hai thanh, uốn khung sườn, dùng vít cố định hai thanh phía bên trái

- Kiểm tra lại hình dạng lồng ngực, bóp bóng đuổi khí, đóng vết mổ.

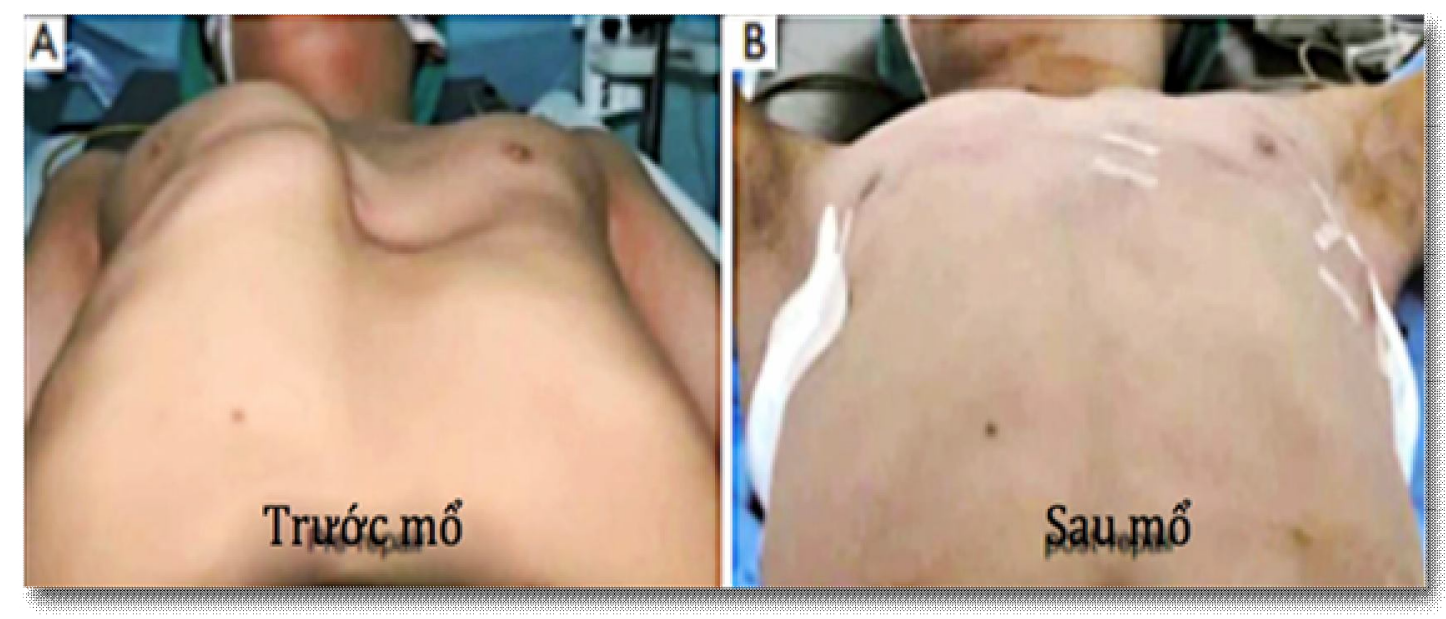

Hình 9: Hình ảnh bệnh nhân truớc và sau phẫu thuật 


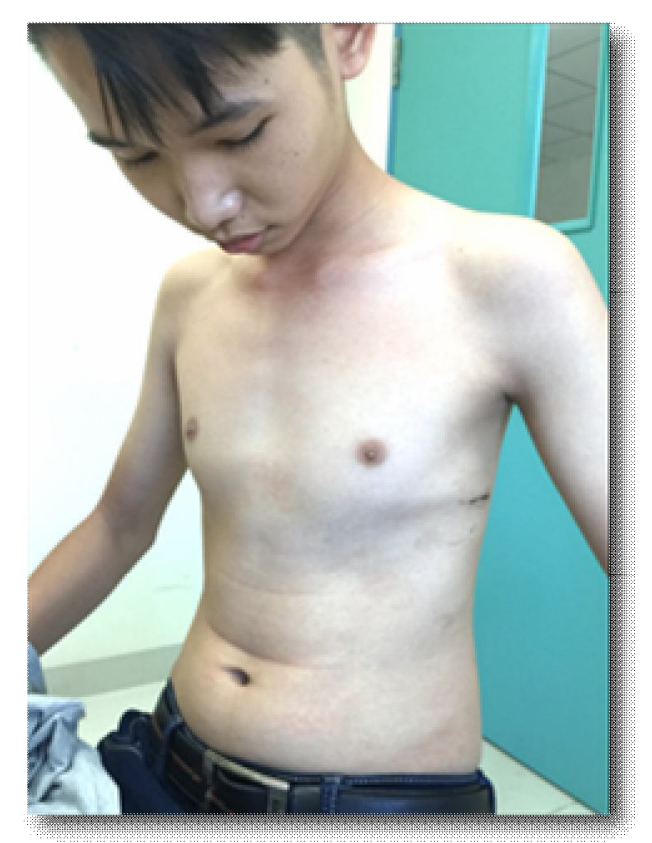

Hình 10: Bệnh nhân sau phẫu thuật Sandwich

\subsection{Theo dõi và xử lý tai biến}

\section{- Theo dõi sau mổ} giờ đầu.

+ Huyết động, hô hấp, dẫn lưu, trong 24

+ Chụp Xquang ngực tại giường

+ Giảm đau hiệu quả, hút đàm rãi nhằm tránh biến chứng xẹp phổi.

+ Vật lý trị liệu hô hấp tích cực sau mổ.

\section{- Xử trí tai biến}

+ Chảy máu sau mổ: Theo dõi sát dẫn lưu tại hồi tỉnh, nếu máu ra nhiều $>1000 \mathrm{ml}$ hoặc $>200 \mathrm{ml} /$ giờ trong 2-3 giờ, phải mổ nội soi hoặc mở ngực cầm máu cấp cứu.

+ Xẹp phổi sau mổ: do người bệnh không thở tốt và bít tắc đờm rãi sau mổ. Cần phải giảm đau tốt cho người bệnh, người bệnh cần ngồi dậy sớm, vỗ rung và ho khạc đờm rãi. Nếu cần có thể soi hút phế quản.

+ Tràn khí màng phổi: Tràn khí ít không cần can thiệp, tràn khí nhiều bên $(\mathrm{T})$ người bệnh có biểu hiện suy hô hấp đặt thêm dẫn lưu màng phổi $(\mathrm{T})$

\section{KÊT QUẢ}

Tại BV Đại học Y Dược TP. Hồ Chí Minh, chúng tôi đã thực hiện phẫu thuật Sandwich từ tháng $5 / 2016$ đến nay với tất cả 27 trường hợp bệnh nhân lồi ngực bẩm sinh được phẫu thuật sửa chữa. Kết quả bước đầu khả quan, không ghi nhận biến chứng nghiêm trọng. Trong thời gian tới chúng tôi sẽ tổng hợp kết quả theo dõi điều trị để có những báo cáo chi tiết về hiệu quả của phẫu thuật này trong điều trị dị dạng lồi ngực. 
Bảng 5.1: Đạ̣c điểm bệnh nhân $(n=27)$

\section{Đặc điểm}

\section{Giới tính}

- Nam

- Nữ

\section{Tuổi (năm)}

\section{Triệu chứng cơ năng}

- Không triệu chứng

- Mệt, khó thở khi gắng sức

- Vấn đề thẩm mỹ

\section{Bệnh kết hợp}

- Vẹo cột sống

- Viêm hô hấp kéo dài

- Hen phế quản

- Bệnh tim bẩm sinh

Gia đình có người mắc dị dạng lồng ngực

Phân loại lồi ngực

- Đối xứng

- Không đối xứng

- Lồi ngực kết hợp lõm ngực

\section{Tỉ lệ}

17( 63\%)

10(37\%)

$7(3-20)$

$20(74 \%)$

$7(26 \%)$

$27(100 \%)$

$10(37 \%)$

$3(11,1 \%)$

$4(14,8 \%)$

$2(7,4 \%)$

$1(3,7 \%)$

$4(14.8 \%)$

$11(40,7 \%)$

$9(33,3 \%)$

7 (26\%)

Bảng 5.2: Đặc điểm can thiệp $(n=27)$

\begin{tabular}{ll}
\hline Đặc điểm & Số đo thống kê \\
\hline Thời gian phẫu thuật (phút) & $45 \pm 20$ \\
Đặt dẫn lưu màng phồi ngay sau đặt thanh & $4(14,8 \%)$ \\
Thời gian nằm viện sau phẫu thuật đặt thanh (ngày) & 4 \\
\hline
\end{tabular}

Bảng 5.3: Biến chứng sớm sau phẫu thuật đặt thanh $(n=27)$

\begin{tabular}{ll}
\hline Biến chứng & Tỉ lệ \\
\hline Tràn khí màng phổi tự hấp thu & $7(26 \%)$ \\
Tràn khí màng phổi cần can thiệp & $0(0 \%)$ \\
Tràn dịch, tràn máu màng phổi cần can thiệp & $0(0 \%)$ \\
Tràn khí dưới da & $10(37 \%)$ \\
Máu đông màng phổi & $0(0 \%)$ \\
Viêm phổi & $0(0 \%)$ \\
Xẹp phổi & $0(0 \%)$ \\
Nhiễm trùng thanh kim loại & $0(0 \%)$ \\
Di lệch thanh sớm & $0(0 \%)$
\end{tabular}




\begin{tabular}{ll}
\hline Biến chứng & Tỉ lệ \\
\hline Cần phẫu thuật lại & $0(0 \%)$ \\
Biến chứng nặng, tử vong & $0(0 \%)$ \\
\hline
\end{tabular}

Bảng 5.4: Hiệu quả phuơng pháp điều trị $(n=27)$

\begin{tabular}{lc}
\hline Đánh giá kết quả dựa theo mức độ hài lòng & \\
\hline - Rất tốt & $19(70,4 \%)$ \\
- Tốt & $07(25,9 \%)$ \\
- Chấp nhận được & $01(3,7 \%)$ \\
- Xấu & $0(0 \%)$ \\
\hline
\end{tabular}

\section{BÀN LUẬN}

Lồi ngực ít gặp hơn so với lõm ngực, nhưng các phương pháp điều trị trước đây như phẫu thuật Ravitch thì để lại nhiều di chứng nặng, tàn phá nhiều cấu trúc như cắt cơ, cắt sụn sường, xương ức, sẹo mổ xấu. Do đó các bệnh nhân thường lựa chọn phương pháp điều trị không phẫu thuật như đeo khung chỉnh sửa.

Hầu hết các bệnh nhân đến khám thường không có triệu chứng lâm sàng $(74 \%)$ mà chủ yếu là đến khám vì lí do thẩm mỹ. Có một số bệnh nhân có triệu chứng lâm sàng mệt và khó thở thường rơi vào nhóm bệnh nhân lồi ngực kết hợp lõm ngực làm hạn chế thể tích lồng ngực, chèn ép tim phổi.

Hyung Joo Park là tác giả phương pháp Sandwich, sư dụng nguyên lý tiếp cận xuyên trung thất của Nuss để sửa dị dạng lồi ngực bằng hai thanh kim loại, một thanh trong lồng ngực và một thanh ngoài lồng ngực. Hai thanh này được cố định bằng chỉ thép hoặc bộ vít chuyên dụng, lực ép giữa hai thanh kim loại sẽ giúp ép phần ngực lõm xuống. Đây là phương pháp ít xâm lấn, không cần cắt sụn sườn hay xương ức[7].

Theo tác giả Park, dị dạng lồi ngực được phân làm 3 nhóm chính là lồi ngực đối xứng, lồi ngực không đối xứng và lồi ngực kết hợp lõm ngực. Cách phân loại này chúng tôi nhận thấy đơn giản và dễ áp dụng trong chỉ định điều trị lồi ngực. Bệnh nhân trong nhóm nghiên cứu của chúng tôi có tỉ lệ lồi ngực cân xứng chiếm ưu thế.

Biến chứng sau phẫu thuật thường gặp là tràn khí màng phổi, tràn khí dưới da. Phẫu thuật Sandwich dựa theo nguyên lý tiếp cận xuyên trung thất trước của phẫu thuật Nuss: luồn thanh kim loại từ ngoài thành ngực - vào khoang màng phổi - qua trung thất trước - vào khoang màng phổi đối bên - ra ngoài thành ngực đối bên. Do đó trong quá trình phẫu thuật khó tránh khỏi tràn khí màng phổi. Sau khi chỉnh sửa dị tật hoàn tất, phẫu thuật viên sẽ thực hiện đuổi khí và đóng kín vết mổ. Nếu quá trình phẫu thuật có tổn thương nhu mô phổi, biến chứng tràn khí, tràn máu màng phổi lượng vừa đến nhiều sẽ cần xử trí dẫn lưu màng phổi. Trong nghiên cứu của chúng tôi, có $26 \%$ bệnh nhân có tràn khí màng phổi lượng ít sau mổ phát hiện trên phim $\mathrm{X}$ quang nhưng không có trường hợp nào cần can thiệp dẫn lưu. Có $37 \%$ bệnh nhân có tràn khí dưới da khu trú quanh vết mổ mà không lan rộng, biến chứng này không đáng ngại vì hầu hết khí tự hấp thu sau 2 đến 3 ngày. 
Một số biến chứng khác như: máu đông màng phổi, viêm phổi, xẹp phổi, nhiễm trùng vết mổ và di lệch thanh sớm,... không gặp trong nghiên cứu của chúng tôi.

Về kết quả điều trị, phẫu thuật Sandwich cho hiệu quả điều trị lồi ngực tốt $(96,2 \%)$, tỉ lệ này cũng tương đương so với nghiên cứu của tác giả Park. Điều này cho thấy phương pháp Sandwich là phương pháp điều trị lồi ngực hiệu quả, an toàn phù hợp với nhu cầu thẩm mỹ của bệnh nhân. Tuy nhiên, chúng tôi cần phải theo dõi dài hơn, cho đến khi rút thanh kim loại để có đánh giá chính xác và toàn diện hơn.

\section{KẾT LUẬN}

Phẫu thuật Sandwich là phương pháp mới, ít xâm lấn trong điều trị dị dạng lồi ngực bẩm sinh. Kết quả bước đầu cho thấy đây là phương pháp an toàn, thời gian hồi phục nhanh, hiệu quả và có tính thẩm mỹ cao. Mở ra cơ hội điều trị sửa chửa triệt để cho rất nhiều bệnh nhân bị lồi ngực nhưng trước đây không muốn điều trị vì ngại phẫu thuật (sẹo xấu, biến chứng).

\section{TÀI LIỆU THAM KHẢO}

1. Nuss, Donald and kelly, Robert E. (1998), "A 10-years review of mimimally invasive technique for correction of pectus excavatum", J Pediatr Surg. 33, pp. 545-552.

2. Vĩnh, Vũ Hưu and Khánh, Huỳnh Quang (2015), "Phẫu thuật dị dạng lồi ngực bẩm sinh", Tạp chí phẫu thuật tim mạch và lồng ngục Việt Nam. 10, pp. 45-48.

3. F, Robicsek, JW, Cook, and HK, Daughtery (1979), "Pectus carinatum:

Thorac Cardiovase Surg 78, pp. 52-61.

4. Fonkalsrud, Eric W. (2000), "Surgical Management of Pectus Carinatum", Thoracic and CardiovascularSurgery. 15, pp. 110-117.

5. H, Abramson, J, D'Agostino, and S, Wuscovi (2009), "A 5-year experience with a minimally invasive technique for pectus carinatum repair", Pediatr Surg. 44, pp. 118-123.

6. LR, Pickard, JJ, Tepas, and DW, Shermeta (1979), "Pectus carinatum: Results of surgical therapy", Pediatr Surg. 14, pp. 228-230.

7. Park, Hyung Joo and Kim, Kyung Soo (2016), "The sandwich technique for repair of pectus carinatum and excavatum/carinatum complex", Annals of cardiothoracic surgery. 5, pp. 434-39. 